\title{
HEC MONTREALAL
}

Institut

d'économie appliquée

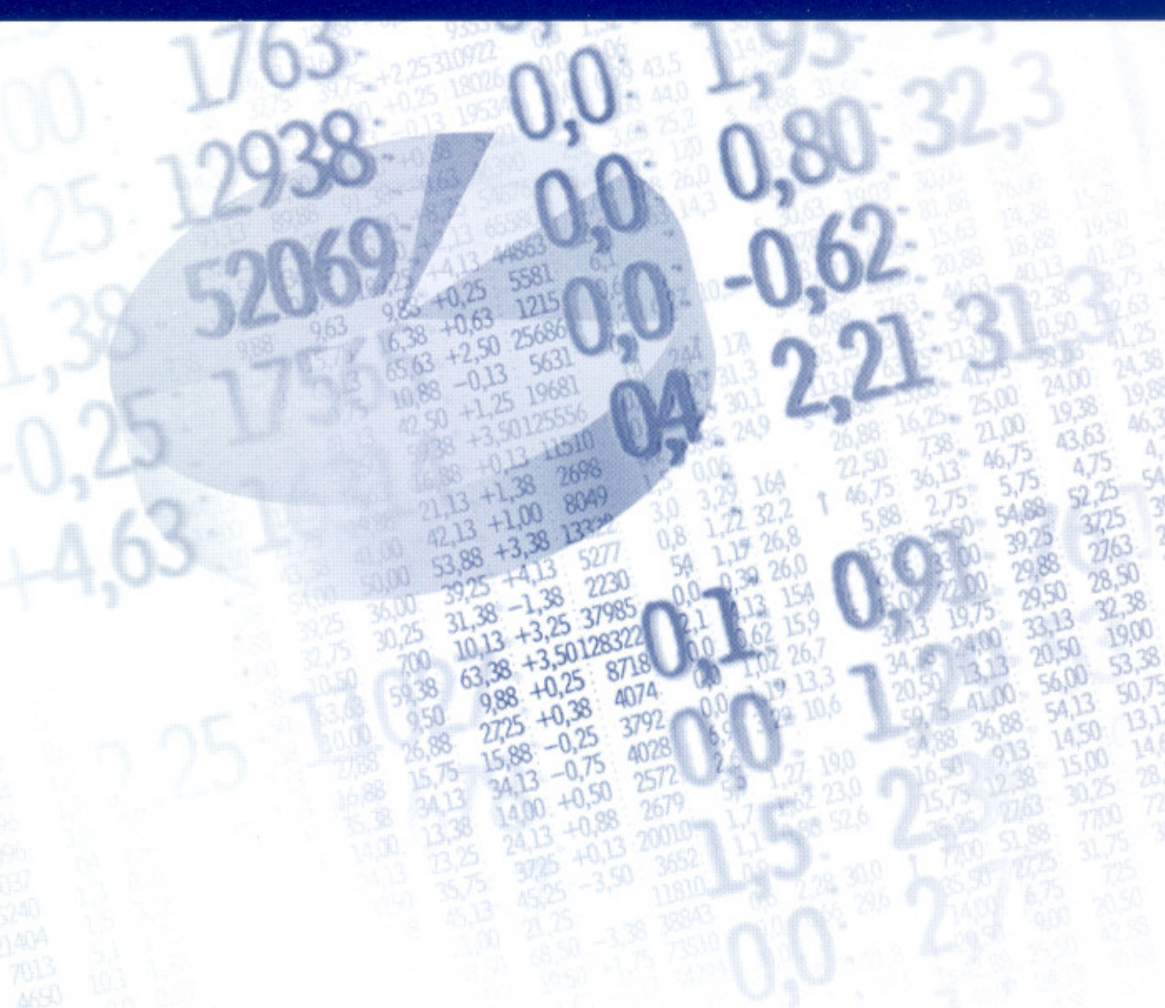

Environmental Policy, Innovation and Performance: New Insights on the Porter Hypothesis

Paul LANOIE Jérémy LAURENT-LUCCHETTI Nick JOHNSTONE Stefan AMBEC 
ISSN : 0825-8643

\title{
Environmental Policy, Innovation and Performance: New Insights on the Porter Hypothesis
}

\author{
Paul LANOIE \\ Jérémy LAURENT-LUCCHETTI \\ Nick JOHNSTONE \\ Stefan AMBEC
}

Cahier de recherche $n^{\circ}$ IEA-07-06

June 2007

Copyright (C) 2007 HEC Montréal.

Tous droits réservés pour tous pays. Toute traduction ou toute reproduction sous quelque forme que ce soit est interdite. Les textes publiés dans la série des Cahiers de recherche HEC n'engagent que la responsabilité de leurs auteurs.

La publication de ce Cahier de recherche a été rendue possible grâce à des subventions d'aide à la publication et à la diffusion de la recherche provenant des fonds de l'École des HEC.

Direction de la recherche, HEC Montréal, 3000, chemin de la Côte-Sainte-Catherine, Montréal (Québec) Canada H3T 2 A7. 



\title{
Environmental Policy, Innovation and Performance : \\ New Insights on the Porter Hypothesis ${ }^{1}$
}

\author{
by \\ Paul Lanoie* Jérémy Laurent-Lucchetti** Nick Johnstone***, and Stefan \\ Ambec****
}

June 2007

\begin{abstract}
Jaffe and Palmer (1997) present three distinct variants of the so-called Porter Hypothesis. The "weak" version of the hypothesis posits that environmental regulation will stimulate certain kinds of environmental innovations. The "narrow" version of the hypothesis asserts that flexible environmental policy regimes give firms greater incentive to innovate than prescriptive regulations, such as technology-based standards. Finally, the "strong" version posits that properly designed regulation may induce cost-saving innovation that more than compensates for the cost of compliance. In this paper, we test the significance of these different variants of the Porter Hypothesis using data on the four main elements of the hypothesised causality chain (environmental policy, research and development, environmental performance and commercial performance). The analysis is based upon a unique database which includes observations from approximately 4200 facilities in seven OECD countries. In general, we find strong support for the "weak" version, qualified support for the "narrow" version, and qualified support for the "strong" version as well.
\end{abstract}

Key words: Porter hypothesis, environmental policy, innovation, environmental performance, business performance.

JEL Codes: L21; M14; Q52; Q55; Q58.

*Professor of Economics, HEC Montreal (paul.lanoie@,hec.ca).

**Ph.D. student, HEC Montreal (jeremy.laurent-lucchetti@hec.ca)

*** Senior Economist, Environment Directorate, OECD (nick.johnstone@oecd.org)

****Research fellow, INRA-GAEL, University of Grenoble (ambec@grenoble.inra.fr)

\footnotetext{
${ }^{1}$ This research was undertaken when Lanoie was on sabbatical at the INRA (Institut National de Recherche Agronomique) research laboratory of Grenoble. Funding from INRA and FQRSC is gratefully acknowledged. We also thank the OECD for providing us with the data.
} 


\section{Introduction}

Porter (Porter, 1991; Porter and van der Linde, 1995) has suggested that pollution is generally associated with a waste of resources, or with lost energy potential: "Pollution is a manifestation of economic waste and involves unnecessary or incomplete utilisation of resources... Reducing pollution is often coincident with improving productivity with which resources are used" (Porter and van der Linde 1995: 98, 105). From this reasoning, Porter argues that 'properly designed environmental regulation can trigger innovation that may partially or more than fully offset the costs of complying with them' $(1995$, p.98). This has come to be known as the Porter Hypothesis (PH). In other words, it is possible to reduce pollution and costs at the same time, resulting in "win-win" situations, contrary to the traditional paradigm. This line of reasoning can be represented by the following diagram:

\section{FIGURE 1}

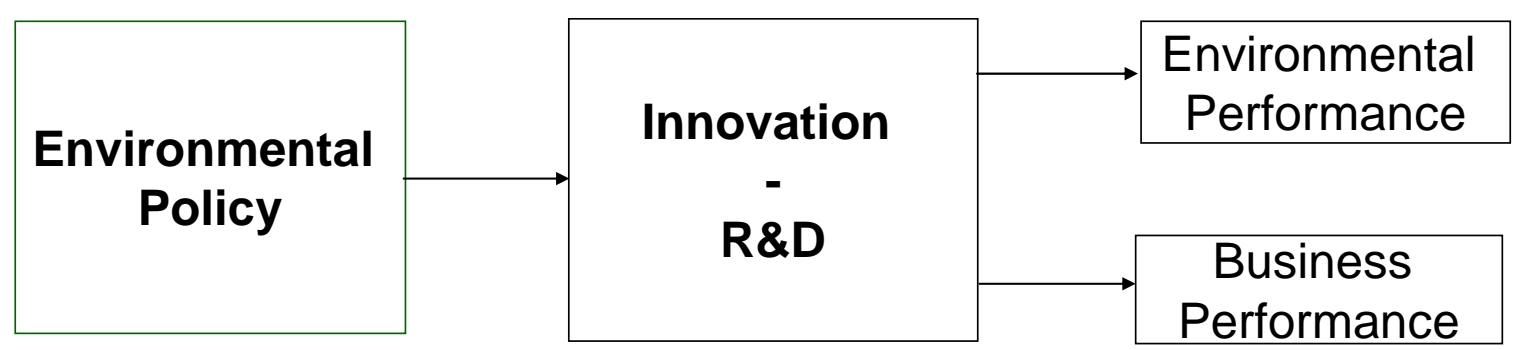

The Porter Hypothesis is controversial. First, the evidence initially provided in its support is based on small number of company case studies, in which firms were able to reduce both their pollution emissions and their production costs. As such, it can hardly be generalized to the entire population of firms. Second, economists would suggest that, in a perfectly competitive economy, if there are opportunities to reduce costs and inefficiencies, companies could identify them by themselves without the help of the government (Oates et al. 1995). 
Indeed, Ambec and Barla (2005) argue that, analytically speaking, for the Porter Hypothesis to be valid, at least one market imperfection is required in addition to the environmental externality. Examples of such market failures include spillovers in knowledge (Jaffe et al., 2004) or in learning-by-doing (Mohr, 2002), or market power (Simpson and Bradford, 1996, Greaker, 2003). Alternatively, they may arise out of systemic organisational failures within the firm, such as contractual incompleteness (Ambec and Barla, 2005), asymmetric information (Ambec and Barla, 2002), and agency control problems (Gabel and Sinclair-Desgagné 2002).

Jaffe and Palmer (1997) present three distinct variants of PH. In their framework, the "weak" version of the hypothesis is that environmental regulation will stimulate certain kinds of environmental innovations, although there is no claim that the direction or rate of this increased innovation is socially beneficial. The "narrow" version of the hypothesis asserts that flexible environmental policy instruments such as pollution charges or tradable permits give firms greater incentive to innovate than prescriptive regulations, such as technology-based standards. Finally, the "strong" version posits that properly designed regulation may induce innovation that more than compensate for the cost of compliance. While many researchers have tested different versions of the Porter Hypothesis empirically, the studies are often partial and the results ambiguous (see next section below).

Given the growing importance of environmental issues in public policy, the challenging and controversial nature of the Porter Hypothesis, and the mitigated nature of the empirical results obtained thus far, assessment of the hypotheses remains an open research question. In this paper, we use a unique database collected by the OECD in 2003 to test the significance of all the links in the causality chain presented above. This database includes observations from approximately 4200 facilities in seven OECD countries (USA, Canada, Japan, Germany, France, Hungary and Norway). Data was collected on the perceived stringency of the environmental policy regime, the use of different policy instruments (command-and-control regulation, environmentally related taxes, etc.), R\&D expenditures allocated specifically to environmental matters, environmental performance with respect to a number of different 
impacts, business performance, and a number of control variables ${ }^{2}$. To our knowledge, this is the first study to test all the variants of the Porter Hypothesis using data on the four main elements of the causality chain (environmental policies of different types, technological innovation, environmental performance and commercial performance). This allows us to obtain greater insight on the mechanisms at play, and on the empirical validity of the Porter Hypothesis.

The rest of the paper is organized as follows. Section 2 provides a brief literature review on the empirical work related to the Porter Hypothesis. A more complete review can be found in Ambec and Barla (2006), Ambec and Lanoie (2007). Section 3 presents the empirical model, the econometric strategy and the data. Section 4 outlines the empirical results, while Section 5 provides concluding remarks

\section{Literature survey}

We distinguish two broad sets of empirical studies. A first set estimates the impact of environmental regulations on firm's innovation policy and technological choice, as measured by investment in $\mathrm{R} \& \mathrm{D}$, in capital and new technologies, or successful patent applications. These studies test the first premise of the Porter Hypothesis that more stringent environmental regulations enhance innovation, or the "weak" version. None of them really present information on the "narrow" version of the $\mathrm{PH}$, although some of them provide indirect evidence in this area as well, as will be discussed below. In the second set, the impact of environmental regulation is estimated on measures of firms' performance, such as productivity and costs. The aim is to test whether more stringent environmental policies can be commercially beneficial to the firm, i.e. the "strong" version. Yet these papers are silent on the process that leads to higher productivity.

In the first set of papers, Jaffe and Palmer (1997) estimate the relationship between total R\&D expenditures and the number of successful patent applications on pollution abatement costs (a proxy for the stringency of environmental regulation) in U.S. manufacturing. They found a

\footnotetext{
${ }^{2}$ Johnstone at al. (2007a) discuss the background of the project, and present an overview of the data.
} 
positive link with $R \& D$ expenditures (an increase of $0.15 \%$ in $R \& D$ expenditures for a pollution abatement cost increase of $1 \%$ ), but no statistically significant link with the number of patents. Also drawing upon U.S. data, but restricting themselves to environmentally-related successful patents, Brunnermeier and Cohen (2003) found a positive but small relationship with environmental regulation. Both studies suggest a weak but positive link between a more stringent environmental policy regimes and the firm's innovation policy. Popp (2006) provides evidence that the introduction of environmental regulation on sulphur dioxide in the U.S., and on nitrogen dioxides in Germany and Japan, was shortly followed by a very significant increase in the number of relevant patents. Arimura et al. (2007a) found a positive and significant relationship between environmental regulation stringency and the probability of investing in environmental R\&D.

Interestingly, in the same vein, two studies find a negative relationship between environmental regulations and investment in capital. Nelson et al. (1993) found that air pollution regulations significantly increased the age of capital in U.S. electric utilities in the 1970s, with the age of capital assumed to be negatively related with environmental performance. According to Gray and Shadbegian (1998, 2003), more stringent air and water regulations have a significant impact on paper mills' technological choice in the U.S. However, their results suggest that it tends to divert investment from productivity to abatement, consistent with the standard paradigm.

The second set of studies, which focuses on the effects of regulation on productivity, has a long tradition in economic literature (see Jaffe et al., 1995, for a review). Most papers reviewed in Jaffe et al. (1995) highlight a negative impact of environmental regulation on productivity. For instance, Gallop and Robert (1983) estimated that $\mathrm{SO}_{2}$ regulations slowed down productivity growth in the U.S. in the seventies by $43 \%$. More recent papers find positive results more in line with the "strong" version. For example, Berman and Bui (2001) report that refineries located in the Los Angeles area enjoyed a significantly higher productivity than other U.S. refineries despite a more stringent air pollution regulation in this area. Similarly, Alpay et al. (2002) estimated the productivity of the Mexican food processing 
industry to be increasing with the pressure of environmental regulation. They therefore suggest that a more stringent regulation is not always detrimental to productivity ${ }^{3}$.

As mentioned above, due to data availability, no study has been able to conduct a direct test of the "narrow" version of $\mathrm{PH}$, which hypothesises that market-based instruments are more likely than traditional "command-and control" measures to induce environmental innovation. However, Burtraw (2000) provides indirect support showing that the change in environmental regulation for $\mathrm{SO}_{2}$ emissions in the U.S. from a technology-based standard with emission caps to an emission allowance trading program in 1990, considerably reduced compliance costs ( $40 \%$ to $140 \%$ lower than projected). It not only encouraged innovation, but also fostered organisational change and competition on upstream input markets. The program was progressive, with permits falling from 2.5 pounds $\mathrm{SO}_{2}$ per Btu of head input in 1995 to 1.2 in 2000, with a banking system. Firms took advantage of relatively low-cost compliance options in the early years of the program to bank allowances and, therefore, smoothed their abatement costs over time. A popular strategy was a switch to the use of coal with lower sulphur content. This resulted in more intense competition in the markets for high-sulphur and low-sulphur coal, which reduced the price of inputs. The industry also experienced technological innovation with respect to fuel blending and in the scrubber market. The former "commandand-control" regulations had not provided incentives to increase $\mathrm{SO}_{2}$ removal by scrubbers by more than the $90 \%$ or $70 \%$ prescribed in the standard. With the new program, there were incentives for further upgrading of scrubber efficiency.

Furthermore, a number of papers have emerged from the OECD project from which the data for this paper is drawn, three of them being more closely related to our research agenda. First, Arimura et al. (2007a) use a bivariate probit model to examine the link between the stringency of environmental policies and environmental R\&D, in which the second dependent variable reflects whether or not a facility has put in place an environmental accounting system. They find that overall perceived stringency is associated with more environmental research, but find no specific influence for any of the individual policy instruments available (technology-based

\footnotetext{
${ }^{3}$ Lanoie et al. (2005) also find positive results when they use a "lagged" regulation variable instead of a contemporaneous one.
} 
standards, performance-based standards, pollution taxes, etc.). However, applying a different model, Johnstone and Labonne (2006) find some evidence for the role of environmentally related taxes in supporting investments in environmental R\&D, while technology-based standards have a negative impact. Third, Darnall et al. (2007) also use a bivariate probit to investigate the relation between environmental performance and business performance. They find that better environmental performance enhances business performance, but that stringency of the environmental policy regime still has a negative impact on business performance. They use a bivariate probit model, transforming their dependent variable into binary form, which is different than the approach adopted here.

\section{Empirical model, econometric strategy and data}

\section{The database}

The data was collected by means of a postal survey undertaken in seven OECD countries (Canada, France, Germany, Hungary, Japan, Norway and the United States) at the facility level in early 2003 (see www.oecd.org/env/cpe/firms for a discussion of sampling procedure and survey protocol). The data covers facilities with more than 50 employees in all manufacturing sectors. The diversity in countries and sectors sampled implies a greater variation across policy frameworks, technological opportunities, and other factors which will allow for the generation of more reliable estimates of different potential determinants of environmental innovation and performance.

Respondents were CEOs and environmental managers. Response rates range from approximately $9 \%$ to $35 \%$, with a weighted mean of almost $25 \%$ (see Table 1 ). For a postal survey this is satisfactory, particularly since previous industrial surveys undertaken in the environmental sphere in many of the countries included in the survey have tended to have very low response rates. For instance, in a review of 183 studies based on business surveys 
published in academic journals Paxson (cited in Dillman, 2000) reports an average response rate of $21 \%{ }^{4}$

Table 1: Response Rate by Country

\begin{tabular}{|l|c|}
\hline & Response Rate \\
\hline Canada & $25.0 \%$ \\
\hline France & $9.3 \%$ \\
\hline Germany & $18.0 \%$ \\
\hline Hungary & $30.5 \%$ \\
\hline Japan & $31.5 \%$ \\
\hline Norway & $34.7 \%$ \\
\hline United States & $12.1 \%$ \\
\hline Total & $24.7 \%$ \\
\hline
\end{tabular}

Table 2 provides data on the number of respondent facilities by industrial sector for the seven countries. While the sectoral data is available at the ISIC two digit level ( 24 sectors), the data is presented in somewhat aggregated form below. A comparison of the population of facilities at the two-digit level with our sample for five of the seven countries can be found at www.oecd.org/env/cpe/firms. In the case of Norway, on the basis of a chi-square test, the sample is not significantly different from the population of facilities in terms of size classes (50-99 employees; 100-249 employees; 250-499 employees; and, > 500 employees). In the case of Germany the distribution of the sample is statistically different from that of the population by sector. Facility size data is not available for Germany. In the case of Japan, the sectoral distribution of the sample is representative, but not the size distribution. For France and Hungary, only firm-level data is available when using a cut-off of 50 employees.

Table 2: Survey Respondents by Sector and by Country

\begin{tabular}{|l|l|c|c|c|c|c|c|c|c|}
\hline & $\begin{array}{l}\text { ISIC } \\
\text { Classification }\end{array}$ & Canada & France & Germany & Hungary & Japan & Norway & USA & Total \\
\hline $\begin{array}{l}\text { Food Beverage and } \\
\text { Tobacco }\end{array}$ & Sectors 15-16 & 23 & 44 & 77 & 68 & 138 & 33 & 37 & 420 \\
\hline $\begin{array}{l}\text { Textiles, Apparel, } \\
\text { Leather }\end{array}$ & Sectors 17-19 & 8 & 13 & 40 & 50 & 72 & 10 & 12 & 205 \\
\hline Wood Products & Sectors 20 \& 36 & 32 & 12 & 26 & 27 & 32 & 49 & 34 & 212 \\
\hline
\end{tabular}

\footnotetext{
${ }^{4}$ While surveys undertaken as part of official data collection exercises may have higher response rates, in many such cases there are legal obligations to respond. Other studies also focus on large firms (e.g. Standard and Poor 500), or firms with other attributes (i.e. listed on the stock exchange), which are likely to have higher response rates. Indeed, given the population sampled, the response rate was higher than had been anticipated.
} 


\begin{tabular}{|c|c|c|c|c|c|c|c|c|c|}
\hline and Furniture & & & & & & & & & \\
\hline $\begin{array}{l}\text { Paper, Publishing } \\
\text { \& Printing }\end{array}$ & Sectors 21-22 & 22 & 17 & 92 & 21 & 129 & 25 & 24 & 330 \\
\hline $\begin{array}{l}\text { Fuel, Chemicals, } \\
\text { Rubber, Plastics }\end{array}$ & Sectors 23-25 & 40 & 48 & 149 & 54 & 195 & 24 & 126 & 636 \\
\hline $\begin{array}{l}\text { Non-Metallic } \\
\text { Mineral Products } \\
\end{array}$ & Sector 26 & 13 & 13 & 34 & 21 & 34 & 14 & 20 & 149 \\
\hline $\begin{array}{l}\text { Basic \& } \\
\text { Fab'd Metals }\end{array}$ & Sectors 27-28 & 42 & 53 & 211 & 52 & 286 & 54 & 129 & 827 \\
\hline $\begin{array}{l}\text { Machinery } \\
\text { And Instruments }\end{array}$ & Sectors 29-33 & 50 & 47 & 227 & 119 & 439 & 55 & 59 & 996 \\
\hline $\begin{array}{l}\text { Motor Vehicles \& } \\
\text { Transp. Eqpmt }\end{array}$ & Sectors $34-35$ & 23 & 19 & 32 & 22 & 113 & 44 & 37 & 290 \\
\hline $\begin{array}{l}\text { Recycling and } \\
\text { Other }\end{array}$ & Sectors 37-39 & 3 & 2 & 10 & 29 & 29 & 1 & 5 & 79 \\
\hline Total & & 256 & 268 & 898 & 463 & 1467 & 309 & 483 & 4144 \\
\hline
\end{tabular}

Significantly, there are a large number of observations from smaller facilities for which response rates are usually much lower in such surveys. Indeed, in many previous studies small and medium sized enterprises are not sampled at all, a significant shortcoming as regulators increasingly seek to influence the behaviour of smaller sources. In the sample, over 2500 facilities can be characterized as small or medium sized enterprises ( $<250$ employees).

One concern with such a survey is that for strategic or other reasons respondents might be inclined to report relatively better environmental performance than is in fact the case. However, this is not a shortcoming which is particular to this study. Indeed, self-reporting is typical when dealing with environmental performance data (e.g., TRI data are self reported). Reassuringly, there is considerable variation in the data, and a fair number of respondents have reported worsening environmental performance over the course of the study period (see below).

It is difficult to corroborate the survey responses with other data sources since data of this kind is rarely collected, and when this is the case either the sample or the questions are very different. However, in the case of Canada a comparison of responses to some of the questions with data obtained from a Statistics Canada study (Environmental Protection Expenditures in the Business Sector) can be found at (http://www.oecd.org/dataoecd/36/35/37265864.pdf). For instance, in the Statistics Canada study, 56\% of facilities report having an EMS (Environmental Management System), while in the OECD sample the corresponding figure is $54 \%$. The proportion of facilities reporting ISO 14001 certification is almost identical in the two samples (19\% and $18 \%$ respectively), mitigating fears of bias. 
Arimura et al. (2007a and 2007b) compare the R\&D expenditure and environmental performance data with data collected from other sources. For the R\&D data, the Japanese sample in the OECD survey was compared with data collected as part of the Survey of Research and Development $2002^{5}$, which has been conducted in Japan for more than a decade. As in the OECD study, respondents were requested to provide information on the specific purposes of the research expenditures, including environmental conservation. Among 4312 facilities which replied to this question in the Japanese survey, $8.4 \%$ or 360 facilities had environment related research expenditure. In the OECD survey, the corresponding figure was $12 \%$. However, since the OECD survey only covers facilities with 50 employees or more and larger facilities are more likely to invest in environmental R\&D, the difference between the two figures may be less than this would imply.

For the environmental performance data, responses in the Japanese sample to a question posed on changes in the use of natural resources in the OECD survey were compared with reported changes in water use in the Japanese Census of Manufactures (Arimura et al. 2007b). At the sectoral level the correlation is positive and significant. Similarly, Darnall (2007), reports a chi-square test comparing sector groupings ("dirty" or "clean" sectors) ${ }^{6}$ with the reported stringency of their environmental policy regime. The results showed that dirty sectors reported that the stringency of their environmental policy regime was greater than facilities operating in clean sectors $(p<0.0001)$, therefore adding confidence to the accuracy of this very important independent variable.

For the business performance variables, data on the change in production at the ISIC two-digit level was drawn from the OECD STAN database for Structural Analysis ${ }^{7}$ and compared this with the data collected on the change in the value of shipments over the period 2000-2002. The correlation between the two variables is positive and significant in all cases, with correlation coefficients in excess of 0.6 for five of seven countries. The outliers are frequently those sectors for which the survey has a small number of observations.

\footnotetext{
${ }^{5}$ Arimura et al. (2005) provide a basic review of the descriptive statistics of Japanese R\&D Survey with focus on $R \& D$ activities for environmental purposes.

${ }^{6}$ This grouping relies on an existing taxonomy of U.S. manufacturing sectors (Mani and Wheeler, 1997; Gallagher and Ackerman, 2000).

${ }^{7}$ http://www.oecd.org/document/15/0,2340,en_2649_201185_1895503_1_1_1_1,00.html
} 


\section{The model and the econometric strategy}

Following the representation of the Porter hypothesis depicted in Figure 1, the three "versions" will be tested by estimating the following three equations, using a two-stage estimation procedure with proper instruments: i) an Environmental R\&D equation; ii) an Environmental performance equation, and iii) a Business performance equation.

(1) ENVIRONMENTAL R\&D $=\beta_{0}+\beta_{1}$ STRINGENCY $1+\beta_{2}$ STRINGENCY3 $+\beta_{3}$ TECHSTANDARDS $1+\beta_{4}$ TECH-STANDARDS $2+\beta_{5}$ TECH-STANDARDS $3+\beta_{6}$ PERF-STANDARDS 1 $+\beta_{7}$ PERF-STANDARDS $2+\beta_{8}$ PERF-STANDARDS $3+\beta_{9}$ TAX $1+\beta_{10}$ TAX $2+\beta_{11}$ TAX $3+\Sigma \beta_{\mathrm{i}}$ COUNTRY $_{\mathrm{i}}+\Sigma \beta_{\mathrm{j}}$ SECTOR $_{\mathrm{j}}+\beta_{28}$ AGE $+\beta_{29}$ LOG (EMPLOYMENT) $+\beta_{30}$ LOG (EMPLOYMENT) ${ }^{2}$ $+\beta_{31}$ CONCENTRATION $1+\beta_{32}$ CONCENTRATION $2+\beta_{33}$ MULTI-FACILITY $+\beta_{34}$ FIRM INTL + $\beta_{35}$ FIRM QUOTED $+\beta_{36}$ PRIMARY CUST $+\beta_{37}$ MARKETSCOPE $1+\beta_{38}$ MARKETSCOPE $2+\beta_{39}$ MARKETSCOPE3 $+\beta_{40}$ INSTRUMENT R\&D $+\varepsilon_{\mathrm{i}}$

(2) ENVIRONMENTAL PERF. $=\delta_{0}+\delta_{1}$ STRINGENCY $1+\delta_{2}$ STRINGENCY $3+\delta_{3}$ TECHSTANDARDS $1+\delta_{4}$ TECH-STANDARDS $2+\delta_{5}$ TECH-STANDARDS $3+\delta_{6}$ PERF-STANDARDS 1 $+\delta_{7}$ PERF-STANDARDS $2+\delta_{8}$ PERF-STANDARDS $3+\delta_{9}$ TAX $1+\delta_{10}$ TAX $2+\delta_{11}$ TAX $3+\Sigma \delta_{\mathrm{i}}$ COUNTRY $_{\mathrm{i}}+\Sigma \delta_{\mathrm{j}}$ SECTOR $_{\mathrm{j}}+\delta_{28}$ AGE $+\delta_{29}$ LOG $_{\text {(EMPLOYMENT) }}+\delta_{30}$ LOG (EMPLOYMENT) $^{2}$ $+\delta_{31}$ CONCENTRATION $1+\delta_{32}$ CONCENTRATION $2+\delta_{33}$ MULTI-FACILITY $+\delta_{34}$ FIRM INTL + $\delta_{35}$ FIRM QUOTED $+\delta_{36}$ PRIMARY CUST $+\delta_{37}$ MARKETSCOPE $1+\delta_{38}$ MARKETSCOPE $2+\delta_{39}$ MARKETSCOPE $3+\delta_{40}$ INSTRUMENT ENV PERF $+\delta_{41}$ FIT ENVIRONMENTAL R\&D $+\eta_{\mathrm{i}}$

(3) BUSINESS PERF. $=\theta_{0}+\theta_{1}$ STRINGENCY1 $+\theta_{2}$ STRINGENCY3 +

$\theta_{3}$ TECH-STANDARDS $1+\theta_{4}$ TECH-STANDARDS $2+\theta_{5}$ TECH-STANDARDS $3+\theta_{6}$ PERFSTANDARDS $1+\theta_{7}$ PERF-STANDARDS $2+\theta_{8}$ PERF-STANDARDS $3+\theta_{9}$ TAX1 $+\theta_{10}$ TAX2 + $\theta_{11}$ TAX3 $+\Sigma \theta_{\mathrm{i}}$ COUNTRY $_{\mathrm{i}}+\Sigma \theta_{\mathrm{j}}$ SECTOR $_{\mathrm{j}}+\theta_{28}$ AGE $+\theta_{29}$ LOG (EMPLOYMENT) $+\theta_{30}$ LOG $\left(\right.$ EMPLOYMENT $^{2}+\theta_{31}$ CONCENTRATION1 $+\theta_{32}$ CONCENTRATION $2+\theta_{33}$ MULTI-FACILITY $+\theta_{34}$ FIRM INTL $+\theta_{35}$ FIRM QUOTED $+\theta_{36}$ PRIMARY CUST $+\theta_{37}$ MARKETSCOPE $1+$ $\theta_{38}$ MARKETSCOPE $2+\theta_{39}$ MARKETSCOPE $3+\theta_{40}$ FIT

ENVIRONMENTAL R\&D $+\theta_{41}$ FIT ENVIRONMENTAL PERF $+\lambda_{\mathrm{i}}$ 
where the $\beta_{\mathrm{k}}, \delta_{\mathrm{k}}$ and $\theta_{\mathrm{k}}$ are parameters to be estimated, and $\varepsilon_{\mathrm{i}}, \eta_{\mathrm{i}}$ and $\lambda_{\mathrm{i}}$ are error terms: $\varepsilon_{\mathrm{i}} \sim \mathrm{N}\left(0, \sigma^{2}\right), \eta_{\mathrm{i}} \sim \mathrm{N}(0,1)$. and $\lambda_{\mathrm{i}} \sim \mathrm{N}(0,1)^{8}$.

\section{Dependent variables}

Table 3 provides the definition and descriptive statistics for all the variables used in the analysis. The three dependent variables are defined as follows. ENVIRONMENTAL R\&D is a 0,1 variable which takes the value 1 when the respondent answered "Yes" to the following question: Does your facility have a budget for research and development specifically related to environmental matters?, and 0 otherwise.

To construct the ENVIRONMENT PERF variable, we combine the answers to the two following questions for five different impact areas (i.e. use of natural resources, solid waste, wastewater, local and regional air pollutants, and global air pollutants):

A) How important do you consider each of the following potential negative environmental impacts from your facility's products and production processes? (no negative impact, moderately negative impact, very negative impact, not applicable)

B) Has your facility experienced a change in the environmental impacts per unit of output of its products or production processes in the last three years with respect to the following? (significant increase, increase, no change, decrease, significant decrease, not applicable)

Observations from respondents who indicated that the impact area is 'not applicable' are treated as missing.

For each type of environmental impact, we multiply the perceived "importance" of the problem (scaled from 1 to 3 ) and the perceived "change" (scaled from 1 to 5) that occurred in the last three years. These values are then summed across the five impact areas, to give a

\footnotetext{
$8: \eta_{\mathrm{i}}$ and $\lambda_{\mathrm{i}}$ are, formally, the error terms of the model involving the unobserved latent variables.
} 
potential maximum of 75 and minimum of 15 . The following figure provides the distribution the ENVIRONMENTAL PERFORMANCE variable on a scale ${ }^{9}$ from 15 to 75.

\section{FIGURE 2}

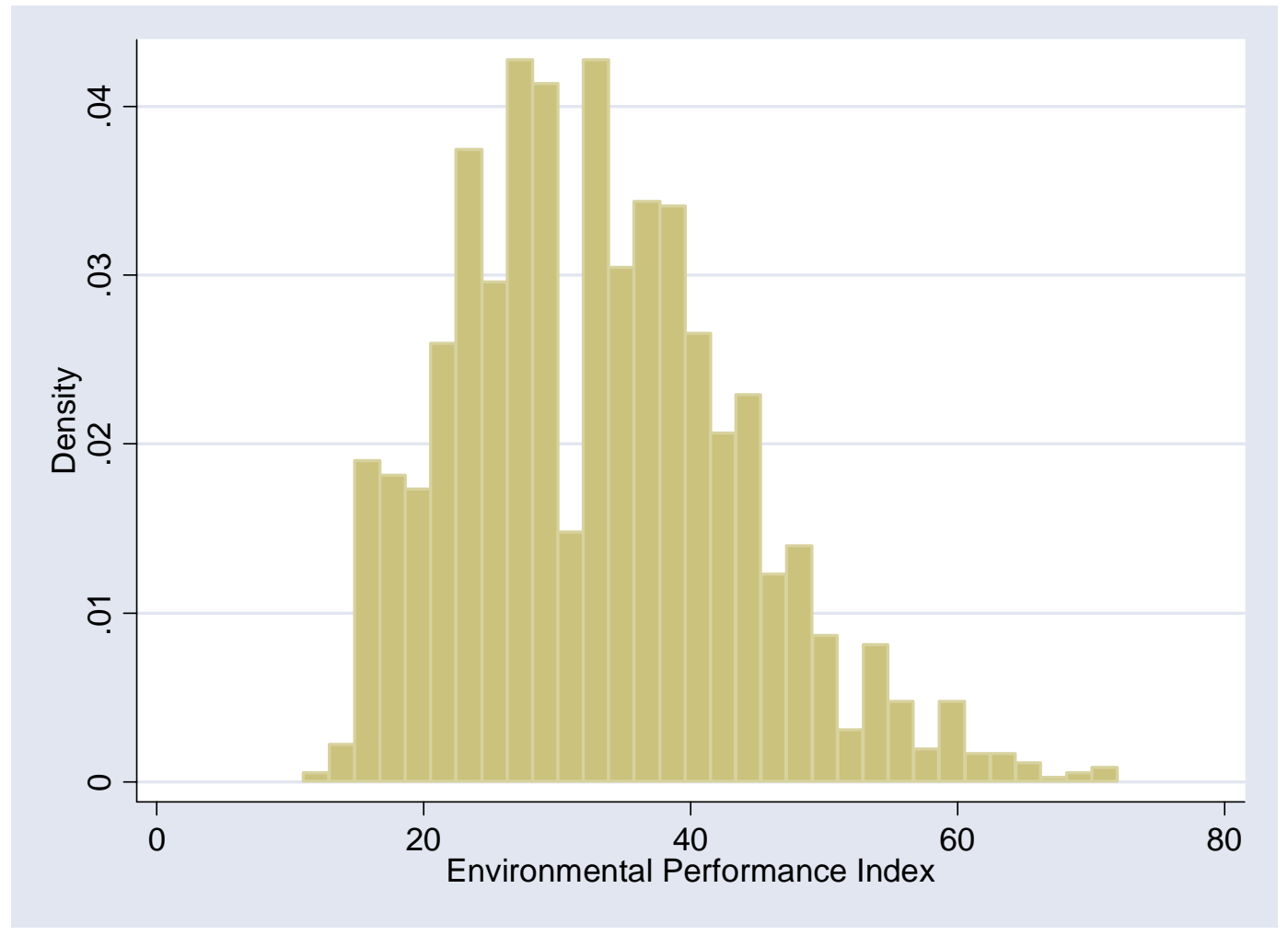

Previous authors who have used this database (Johnstone et al, 2007b, Darnall et al., 2007) have constructed a binary variable taking the value 1 when a facility reports that there has been a "significantly decrease" or "decrease" with respect to a specific environmental impact, and 0 otherwise. As such, information with respect to the perceived potential "importance" of the impact arising out of the facility's specific production activities has not been applied. We consider our measure of environmental performance to be richer.

For the BUSINESS PERF variable, we use the answer, on a five-point scale, to the following question:

\footnotetext{
${ }^{9}$ The scale could be below 15 for facilities which reported that one or more impact areas was "not applicable".
} 
How would you assess your facility's overall business performance over the last three years? (revenue has been so low as to produce large losses, revenue has been insufficient to cover costs, revenue has allowed us to break even, revenue has been sufficient to make a small profit, revenue has been well in excess of costs)

Given the nature of these three dependent variables, equation (1) is estimated using a Probit model, equation (2) with an OLS, and equation (3) with an Ordered Probit. In addition, for the ENVIRONMENTAL R\&D equation we use an instrument because of suspected simultaneity between ENVIRONMENTAL R\&D and BUSINESS PERF (as well as between ENVIRONMENTAL R\&D and ENVIRONMENT PERF). Specifically, the decision to invest in environmental $R \& D$ may be influenced by unobserved factors which also affect business performance (and environmental performance). Such factors might include the personal preferences of the manager (or the CEO), the structure of the firm, the links between the R\&D department and the decision makers in the firm, etc. If the potential simultaneity between the two variables is not addressed, we would obtain biased estimates.

As such, it is necessary to identify an instrument correlated with the decision to invest in environmental $\mathrm{R} \& \mathrm{D}$, but which is not directly correlated with business performance (and environmental performance). We use the average percentage of facilities in the same sector and same country with a specific environmental $R \& D$ budget as the instrument (INSTRUMENT R\&D). This is assumed to be correlated with the decision to undertake environmental $R \& D$ in the specific facility, but to have an insignificant impact on the facility's business performance. This type of instrument is common in the industrial organization literature ${ }^{10}$ where, for instance, the average price of a product on markets different than that under consideration (i.e. neighbouring states) is widely used.

When we estimate the ENVIRONMENT PERF EQUATION, we use an instrument defined as the average environmental performance of the facilities in the same sector in the same country (INSTRUMENT ENV PERF). In this equation, FIT ENVIRONMENTAL R\&D is the fitted value of the preceding equation. In the BUSINESS PERF equation, the variable FIT

\footnotetext{
${ }^{10}$ See Hausman et al. (1994), Hausman (1996), Nevo (2000 a, b).
} 
ENVIRONMENTAL PERF is the fitted value of the preceding equation ${ }^{11}$, and the variable FIT ENVIRONMENTAL R\&D is also the fitted value of the ENVIRONMENTAL R\&D equation.

\section{Independent variables}

\section{Environmental R\&D Equation}

Regarding the environmental policy variables, we note first that the STRINGENCY indicators are obtained from responses to the following question:

How would you describe the environmental policy regime to which your facility is subject?

- Not particularly stringent, obligations can be met with relative ease

- Moderate stringency, require some managerial and technological responses

- Very stringent, has a great deal of influence on decision-making in the facility

Given that it might be considered arbitrary to apply a continuous variable with the scale 1,2 , and 3, and that perceived stringency could vary in a non-linear fashion, we constructed two dummy variables STRINGENCY1, which is equal to 1 if the answer is 1 , and 0 otherwise; and STRINGENCY3, which is equal to 1 when the answer is 3 , and 0 otherwise (STRINGENCY2 is the reference case). According to $\mathrm{PH}$, the sign of the estimated coefficient of STRINGENCY3 should be positive. It is expected that STRINGENCY1 will have a negative impact.

For four different types of environmental policy instrument (technology-based standard, performance-based standard, input tax, emission or effluent charge) respondents were requested to:

\footnotetext{
${ }^{11} \mathrm{PH}$ does not necessarily imply that the environmental performance influences business performance, so the business performance equation was also estimated without the variable ENVIRONMENTAL PERF.
} 
Please assess the following environmental policy instruments in terms of their impacts on your facility's production activities. (not important, moderately important, very important, not applicable).

In this case, "not applicable" is taken as the reference case. TECH-STANDARDS1 is a dummy variable equal to 1 when the answer for the item "technology-based standards" are considered not important, and zero otherwise, and so on for the other two TECHSTANDARDS variables and for the PERF-STANDARDS variables. The variables TAX1, TAX2 and TAX3 are similar, but they combine the two items "input taxes", and "emission or effluent taxes or charges" 12 . Again, with regards to the "weak version" of the $\mathrm{PH}$, all these variables are expected to have a positive influence on the probability to have a specific R\&D budget allocated to environmental matters. In line with the "narrow" version, we expect the more flexible tax policies to have a stronger impact than the regulatory measures (technologybased and performance-based standards).

Concerning the control variables, we first introduce COUNTRY and SECTOR dichotomous variables to capture unobservable specific influences related to the country or the sector of activity. The AGE of the facility is included, and its expected sign is ambiguous. On the one hand, older facilities may use older technologies, and therefore have a greater need for research and development on environmental matters. On the other hand, older facilities may face less stringent regulations than new ones, and have lower incentives to do environmental R\&D. We use the EMPLOYMENT level as a proxy for the size of the facility. In the Schumpeterian view, it is expected that larger facilities are more likely to do research, but that this relation may be non-linear (EMPLOYMENT ${ }^{2}$ ) (see Jaumotte and Pain 2005 for a review.) As in many other papers, we use these measures in log form. Standard theory has ambiguous predictions concerning the impact of market concentration on innovation (CONCENTRATION1 and CONCENTRATION2) ${ }^{13}$. The Schumpeterian view predicts that

\footnotetext{
${ }^{12}$ Other policy instruments were also listed in this question like subsidies or voluntary agreements. However, given that, in policy discussions, the focus is often put on the "command-and-control" versus "economic instruments" debate, and in order to avoid multicollinearity problems, we kept only the items mentioned above.

${ }^{13}$ The CONCENTRATION variables are obtained from responses to the following question: With how many other firms did your facility compete on the market for its most commercially important product within the past three years? (Please tick only one box). 1. Less than $5 ; 2.5-10 ; 3$. Greater than 10.
} 
facilities in more concentrated industries are more likely to invest in research since they can enjoy the monopoly rents from any innovations identified as a consequence of the R\&D. In contrast, in the Arrovian view, firms which enjoy market power tend "to rest on their laurels" (e.g., Tirole, 1989), which leads to the opposite prediction.

We also include three variables to capture important characteristics of the firm to which the facility belongs. First, the variable MULTI-FACILITY reflects whether the facility belongs to a multi-facility enterprise. It is expected that facilities in multi-facility firms are more likely to invest in research on environmental matters because of the potential spillovers across plants. Second, a variable reflects if the firm's head office is located in a foreign country (FIRM INTL), in order to test whether or not multinational firms are more likely to be concerned with environmental issues, and to take concrete actions, such as devoting a specific budget to R\&D. Third, FIRM QUOTED reflects whether or not a facility belongs to a company quoted on the stock market. It is expected that firms on the stock exchange are more likely to signal their concern for environmental matters to potential investors. In addition, due to the difficulties frequently encountered in financing $\mathrm{R} \& \mathrm{D}$, a stock market listing may ease some of the constraints.

Finally, we include variables to reflect the characteristics of the facility's market. The first one, PRIMARY CUST is equal to 1 when the primary customers of the facility's products are "households" or "wholesalers or retailers", and 0 otherwise. In the same vein as with the preceding variable, it is expected that facilities who deal directly with customers or retailers may have greater incentive to signal their actions related to environmental issues. We also have three variables to capture the spatial scope of the market in which they operate (MARKETSCOPE1, MARKETSCOPE2, MARKETSCOPE3) ${ }^{14}$. It is expected that facilities with a more global market scope are more likely to have a specific environmental R\&D budget.

CONCENTRATION1 is a dummy variable equal to 1 if the answer is 1 and 0 otherwise; CONCENTRATION2 is a dummy variable equal to 1 if the answer is 2 and 0 otherwise.

${ }^{14}$ The MARKETSCOPE variables are obtained from responses to the question: What best characterises the scope of your facility's market? (Please tick only one box) 1.Local ; 2. National ; 3.Regional (neighbouring countries) ; 4. Global. MARKETSCOPE2 is a dummy variable equal to 1 if the answer is 2 and 0 otherwise;MARKETSCOPE3 is a dummy variable equal to 1 if the answer is 3 and 0 otherwise, etc. 


\section{Environmental Performance Equation}

In this equation, we have the same independent variables, except for the instrument, and for the FIT ENVIRONMENTAL R\&D variable, which is the fitted value of the preceding equation. This variable is expected to positively influence environmental performance. Regarding the expected signs of the other independent variables, we postulate that the same arguments prevailing in the preceding equation are relevant, i.e., variables influencing positively the probability to have a specific environmental $R \& D$ budget are likely to influence positively the environmental performance. Regarding the environmental policy variables, economic analysis does not provide insights as to whether 'direct' regulations or 'marketbased' instruments are more likely to induce increased efforts to improve environmental performance at the level of the individual facility. In the face of facility heterogeneity, there are nevertheless good reasons to expect that variation in environmental performance will be greater under market-based instruments than under direct regulations. Indeed, the case for introducing market-based instruments is typically made on the basis of the cost-savings which arise out of the efficient allocation of efforts across heterogeneous facilities, not with respect to enhanced environmental effectiveness within facilities. ${ }^{15}$

\section{Business Performance Equation}

Here also, the same independent variables as in the preceding equation are used, except that we add the variable FIT ENVIRONMENTAL PERF. In line with Porter's argument and with results obtained in previous studies (e.g. Darnall et al., 2007), the coefficient of this variable should be positive, as well as the coefficient of the FIT ENVIRONMENTAL R\&D variable. The arguments concerning the expected signs for the other independent variables are fairly intuitive. In the next section, they will be discussed in details for the variables that turn out to be significant.

\footnotetext{
${ }^{15}$ However, there is good reason to believe that 'cap-and-trade' permit systems will be more environmentally effective at the economy-wide level than other measures of equal stringency. See Johnstone (2005).
} 
Table 3: Descriptive statistics for the main variables

\begin{tabular}{|c|c|c|c|c|c|}
\hline Variable & Description & Mean & Std. Dev. & Min & Max \\
\hline $\begin{array}{l}\text { Environmental } \\
\text { R\&D }\end{array}$ & Does facility have environmental R\&D budget? $(0=$ no; $1=y e s)$ & 0.093 & 0.290 & 0 & 1 \\
\hline $\begin{array}{l}\text { Environmental } \\
\text { Perf. }\end{array}$ & Index of environmental performance (scale $=15$ to 75, see footnote 90 ) & 33.022 & 10.562 & 11 & 72 \\
\hline Business Perf. & $\begin{array}{l}\text { Assessment of overall business performance }(1=\text { revenue has been so low as to } \\
\text { produce large losses; } 2=\text { revenue has been insufficient to cover costs; } \\
3=\text { revenue has allowed us to break even; } 4=\text { revenue has been sufficient to } \\
\text { make a small profit; } 5=\text { revenue has been well in excess of costs })\end{array}$ & 3.460 & 0.989 & 1 & 5 \\
\hline Stingencyl & $\begin{array}{l}\text { The environmental policy regime is not particularly stringent, obligations can } \\
\text { be met with relative ease }(0=\text { no, } 1=\text { yes })\end{array}$ & 0.360 & 0.480 & 0 & 1 \\
\hline Stringency3 & $\begin{array}{l}\text { The environmental policy regime is very stringent, it has a great deal of } \\
\text { influence on decision-making in the facility }(0=\text { no, } 1=\text { yes })\end{array}$ & 0.159 & 0.366 & 0 & 1 \\
\hline Tech-standards 1 & The technology-based standards are not important $(0=$ no, $1=$ yes $)$ & 0.157 & 0.364 & 0 & 1 \\
\hline Tech-standards2 & The technology-based standards are moderately important $(0=$ no, $1=$ yes $)$ & 0.355 & 0.478 & 0 & 1 \\
\hline Tech-standards3 & The technology-based standards are very important $(0=$ no, $1=$ yes $)$ & 0.207 & 0.405 & 0 & 1 \\
\hline Perf-standards1 & The performance-based standards are not important $(0=$ no, $1=$ yes $)$ & 0.112 & 0.315 & 0 & 1 \\
\hline Perf-standards2 & The performance-based standards are moderately important $(0=$ no, $1=$ yes $)$ & 0.387 & 0.487 & 0 & 1 \\
\hline Perf-standards3 & The performance-based standards are very important $(0=$ no, $1=$ yes $)$ & 0.308 & 0.462 & 0 & 1 \\
\hline Tax1 & The environmental taxes are not important $(0=$ no, $1=$ yes $)$ & 0.233 & 0.423 & 0 & 1 \\
\hline Tax2 & The environmental taxes are moderately important $(0=$ no, $1=$ yes $)$ & 0.475 & 0.499 & 0 & 1 \\
\hline $\operatorname{Tax} 3$ & The environmental taxes are very important $(0=$ no, $1=$ yes $)$ & 0.311 & 0.463 & 0 & 1 \\
\hline USA & Dummy for the country (omitted = Canada) & 0.117 & 0.321 & 0 & 1 \\
\hline Germany & $"$ & 0.215 & 0.411 & 0 & 1 \\
\hline Hungary & $"$ & 0.111 & 0.315 & 0 & 1 \\
\hline Japan & $"$ & 0.358 & 0.479 & 0 & 1 \\
\hline France & $"$ & 0.064 & 0.245 & 0 & 1 \\
\hline Norway & $"$ & 0.074 & 0.262 & 0 & 1 \\
\hline Food & Dummy for the sector (omitted = recycling) & 0.100 & 0.300 & 0 & 1 \\
\hline Leather & $"$ & 0.049 & 0.216 & 0 & 1 \\
\hline Wood & $"$ & 0.051 & 0.219 & 0 & 1 \\
\hline Pulp & 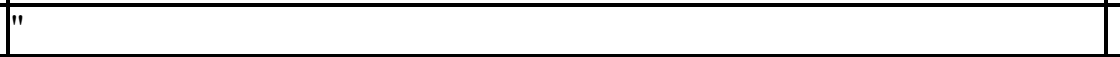 & 0.079 & 0.270 & 0 & 1 \\
\hline Coke & 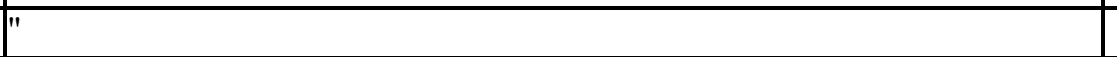 & 0.152 & 0.359 & 0 & 1 \\
\hline Nonmetal & $"$ & 0.036 & 0.185 & 0 & 1 \\
\hline Metal & 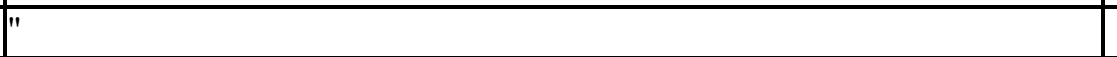 & 0.198 & 0.398 & 0 & 1 \\
\hline Machinery & $"$ & 0.238 & 0.426 & 0 & 1 \\
\hline Motor & $"$ & 0.069 & 0.254 & 0 & 1 \\
\hline Age & Age of the facility & 36.135 & 21.582 & 0 & 99 \\
\hline Log (employment) & \# of full time employees in facility (log) & 5.106 & 1.047 & 0.6931 & 10.2617 \\
\hline Log (employment) $)^{2}$ & Squared \# of full time employees in facility (log) & 27.169 & 11.481 & 0.4804 & 105.3044 \\
\hline Concentration1 & Number of competitors (less than 5 or not) & 0.264 & 0.441 & 0 & 1 \\
\hline
\end{tabular}




\begin{tabular}{|c|c|c|c|c|c|}
\hline Concentration 2 & Number of competitors (between 5 and 10 or not) & 0.344 & 0.475 & 0 & 1 \\
\hline Multi-facility & Does the facility belong to a multi-facility enterprise $(0=$ no, $1=y e s)$ & 0.520 & 0.500 & 0 & 1 \\
\hline Firm intl & Head office located in foreign country? $(0=$ no; $1=y e s)$ & 0.120 & 0.325 & 0 & 1 \\
\hline Firm quoted & Listed on a stock exchange? $(0=$ no; $1=$ yes $)$ & 0.167 & 0.373 & 0 & 1 \\
\hline Primary cust & $\begin{array}{l}\text { Primary customers of the facility's products }(1=\text { "Households" or } \\
\text { "Wholesalers or retailers", } 0 \text { otherwise })\end{array}$ & 0.373 & 0.484 & 0 & 1 \\
\hline Marketscope1 & Scope of facility's market (local or not) & 0.409 & 0.492 & 0 & 1 \\
\hline Marketscope2 & Scope of facility's market (national or not) & 0.409 & 0.492 & 0 & 1 \\
\hline Markescope3 & Scope of facility's market (regional or not) & 0.108 & 0.310 & 0 & 1 \\
\hline
\end{tabular}

\section{Empirical results}

Table 4 reports the estimated coefficients in our three main equations. Panel A presents the results of the Environmental R\&D equation, Panel B the Environmental Performance equation, and Panel $\mathrm{C}$ the Business Performance equation. In each Panel, Column 1 refers to the model as presented in equations (1), (2) and (3). In order to have a sense of the robustness of our results, we also provide three alternative approaches. In each case, we define one of the three dependent variables in an alternative manner. In column (2) of each panel, we repeat the same exercise, but with total R\&D expenditures as a measure of innovation generated by more rigorous environmental regulation ${ }^{16}$. Indeed, Porter suggests that the stringency of environmental policies should lead to more innovation, but he does not mention specifically the effect on environmental R\&D. Jaffe and Palmer (1997) use total R\&D in their evaluation of the PH. In column (3) of each panel, we repeat the exercise using a " 0,1 " measure of environmental performance, as discussed above and suggested by Darnall et al. (2007) and Johnstone et al. (2007b). Finally, in column (4) of each panel, we use the evolution of shipments instead of profits as a measure of business performance. In this case, the environmental R\&D and environmental performance equations are not affected.

Column (1) remains our "preferred" specification: environmental R\&D is more likely to be affected by environmental policies than total R\&D; our measure of environmental performance is more precise and complete than a " 0,1 " measure; and, profits is better

\footnotetext{
${ }^{16}$ Since we refer to total R\&D expenditures, an OLS model is used. As 533 facilities reported no R\&D expenditures, the dependent variable is truncated and we also estimated the model with a Tobit. The results (available upon request) were very similar to those reported in Table 4.
} 
approximation of business performance than sales. We will thus start our discussion by focusing on column (1). 
PANEL A

\begin{tabular}{|c|c|c|c|c|}
\hline Dependent variable: & Main Regression (1) & Total R\&D (2) & Env. Perf. Binary (3) & Shipments (4) \\
\hline Environmental R\&D & Coeff. P. Value & P.Value & P. Value & P. Value \\
\hline Stringency1 & $\begin{array}{ll}-.259839 & 0.001 \\
\end{array}$ & $-1.57 \mathrm{e}+08 \quad 0.638$ & $\begin{array}{ll}-.259839 & 0.001 \\
\end{array}$ & $\begin{array}{ll}-.259839 & 0.001\end{array}$ \\
\hline Stringency3 & $.2473861 \quad 0.006$ & $-4.62 \mathrm{e}+08 \quad 0.295$ & $.2473861 \quad 0.006$ & $\begin{array}{ll}.2473861 & 0.006\end{array}$ \\
\hline Tech-standards1 & .0348849 0.752 & $1.23 \mathrm{e}+08 \quad 0.808$ & .0348849 0.752 & .0348849 0.752 \\
\hline Tech-standards2 & $\begin{array}{ll}.082071 & 0.409\end{array}$ & $2.85 \mathrm{e}+08 \quad 0.533$ & $\begin{array}{ll}-082071 & 0.409\end{array}$ & $\begin{array}{ll}-082071 & 0.409\end{array}$ \\
\hline Tech-standards3 & $\begin{array}{ll}.0592128 & 0.619\end{array}$ & $8.96 \mathrm{e}+08 \quad 0.104$ & $\begin{array}{ll}.0592128 & 0.619\end{array}$ & $\begin{array}{ll}.0592128 & 0.619\end{array}$ \\
\hline Perf-standards1 & $.1505738 \quad 0.303$ & $1.63 \mathrm{e}+08 \quad 0.787$ & $.1505738 \quad 0.303$ & $.1505738 \quad 0.303$ \\
\hline Perf-standards2 & $\begin{array}{ll}.2217971 & 0.042\end{array}$ & $\begin{array}{ll}7475385 & 40.987\end{array}$ & $\begin{array}{ll}.2217971 & 0.042\end{array}$ & .2217971 \\
\hline Perf-standards3 & $\begin{array}{ll}228787 & 0.057 \\
\end{array}$ & $-1.19 \mathrm{e}+08 \quad 50.826$ & $.228787 \quad 0.057$ & $.228787 \quad 0.057$ \\
\hline Tax1 & $\begin{array}{ll}-.062489 & 0.476\end{array}$ & $-1.27 \mathrm{e}+08$ & $\begin{array}{ll}-.062489 & 0.476\end{array}$ & $\begin{array}{ll}-.062489 & 0.476\end{array}$ \\
\hline Tax2 & $\begin{array}{ll}-.024468 & 0.742 \\
\end{array}$ & $-1.98 \mathrm{e}+08 \quad 0.547$ & $\begin{array}{ll}-.024468 & 0.742 \\
\end{array}$ & $\begin{array}{ll}-.024468 & 0.742 \\
\end{array}$ \\
\hline Tax3 & $.0228959 \quad 0.790$ & $2.08 \mathrm{e}+08 \quad 0.595$ & .0228959 & .0228959 \\
\hline Age & .0027938 & $\begin{array}{ll}-4866450 & 0.483 \\
\end{array}$ & .0027938 & .0027938 \\
\hline Log (employment) & $\begin{array}{ll}.2385036 & 0.205 \\
\end{array}$ & $-1.20 \mathrm{e}+10 \quad 0.000$ & $\begin{array}{ll}-.2385036 & 0.205 \\
\end{array}$ & $\begin{array}{lll}-.2385036 & 0.205 \\
\end{array}$ \\
\hline Log (employment) $^{2}$ & .0409231 0.014 & $1.21 \mathrm{e}+10 \quad 0.000$ & $\begin{array}{ll}.0409231 & 0.014 \\
\end{array}$ & $\begin{array}{ll}.0409231 & 0.014 \\
\end{array}$ \\
\hline Concentration1 & $.176392 \quad 0.031$ & $-4.94 e+08 \quad 0.176$ & $.176392 \quad 0.031$ & $.176392 \quad 0.031$ \\
\hline Concentration2 & $.19748 \quad 0.009$ & $-4.72 \mathrm{e}+08 \quad 0.152$ & $.19748 \quad 0.009$ & .19748 \\
\hline Multi-facility & $.0572784 \quad 0.402$ & $-3.67 \mathrm{e}+08 \quad 0.220$ & $.0572784 \quad 0.402$ & $.0572784 \quad 0.402$ \\
\hline Firm intl & $\begin{array}{l}.0642464 \quad 0.537 \\
\end{array}$ & $-1.68 \mathrm{e}+08 \quad 0.744$ & $\begin{array}{l}.0642464 \quad 0.537 \\
\end{array}$ & $\begin{array}{ll}-.0642464 \quad 0.537 \\
\end{array}$ \\
\hline Firm quoted & $\begin{array}{ll}0942427 & 0.283 \\
\end{array}$ & $4.41 \mathrm{e}+08 \quad 0.336$ & $.0942427 \quad 0.283$ & $\begin{array}{ll}.0942427 & 0.283 \\
\end{array}$ \\
\hline Primary cust & $.0107136 \quad 0.884$ & $\begin{array}{ll}5.53 \mathrm{e}+08 & 0.084 \\
\end{array}$ & $.0107136 \quad 0.884$ & $\begin{array}{ll}0107136 & 0.884 \\
\end{array}$ \\
\hline Marketscope1 & $-.149377 \quad 0.270$ & $-7.32 \mathrm{e}+08$ & $\begin{array}{ll}-.149377 & 0.270\end{array}$ & $-.149377 \quad 0.270$ \\
\hline Marketscope2 & $\begin{array}{ll}-.1979465 & 0.014 \\
\end{array}$ & $-4.91 \mathrm{e}+08 \quad 0.178$ & $\begin{array}{ll}-.1979465 & 0.014 \\
\end{array}$ & $\begin{array}{ll}-.1979465 & 0.014 \\
\end{array}$ \\
\hline Marketscope3 & $-.0227915 \quad 0.848$ & $1.20 \mathrm{e}+07 \quad 0.981$ & $-.0227915 \quad 0.848$ & $-.0227915 \quad 0.848$ \\
\hline Instrument R\&D & $\begin{array}{ll}4.525124 & 0.000 \\
\end{array}$ & $\begin{array}{ll}9244826 & 0.000 \\
\end{array}$ & $\begin{array}{ll}4.525124 & 0.000\end{array}$ & $4.525124 \quad 0.000$ \\
\hline R-squared & 0.1146 & 0.1142 & 0.1146 & 0.1146 \\
\hline Observations & 3617 & 2503 & 3617 & 3617 \\
\hline
\end{tabular}


PANEL B

\begin{tabular}{|c|c|c|c|c|}
\hline Dependent variable: & Main Regression (1) & Total R\&D (2) & Env. Perf. Binary (3) & Shipments (4) \\
\hline Environmental Perf. & Coeff. P. Value & P.Value & P. Value & P. Value \\
\hline Stringency 1 & -2.564552 .0 .000 & $\begin{array}{ll}-2.726697 & 0.000\end{array}$ & (dropped) & -2.564552 .0 .000 \\
\hline Stringency3 & $1.580575 \quad 0.048$ & $\begin{array}{ll}.495629 & 0.037 \\
\end{array}$ & $\begin{array}{ll}0117417 & 0.654 \\
\end{array}$ & $\begin{array}{ll}1.580575 & 0.048 \\
\end{array}$ \\
\hline Tech-standards1 & $1.856611 \quad 0.033$ & $1.93378 \quad 0.027$ & $.0526249 \quad 0.054$ & $1.856611 \quad 0.033$ \\
\hline Tech-standards2 & $\begin{array}{ll}2.38655 & 0.002 \\
\end{array}$ & $2.545244 \quad 0.001$ & $\begin{array}{ll}.0753608 & 0.002 \\
\end{array}$ & $\begin{array}{ll}2.38655 & 0.002 \\
\end{array}$ \\
\hline Tech-standards3 & $1.712167 \quad 0.068$ & $2.219477 \quad 0.031$ & $.0365303 \quad 0.212$ & $1.712167 \quad 0.068$ \\
\hline Perf-standards1 & $.1369385 \quad 0.908$ & $.2480075 \quad 0.832$ & $.0918775 \quad 0.006$ & $.1369385 \quad 0.908$ \\
\hline Perf-standards2 & $\begin{array}{ll}2.55761 & 0.008 \\
\end{array}$ & $2.559745 \quad 0.005$ & $.1400523 \quad 0.000$ & $\begin{array}{ll}2.55761 & 0.008\end{array}$ \\
\hline Perf-standards3 & $\begin{array}{ll}3.940165 & 0.000 \\
\end{array}$ & $\begin{array}{ll}.870746 & 0.000 \\
\end{array}$ & $.1667656 \quad 0.048$ & $3.940165 \quad 0.000$ \\
\hline Tax1 & $\begin{array}{ll}-.4085853 & 0.546 \\
\end{array}$ & $\begin{array}{ll}-.4945114 & 0.461 \\
\end{array}$ & $\begin{array}{ll}-.0120941 & 0.556 \\
\end{array}$ & $\begin{array}{lll}-.4085853 & 0.546 \\
\end{array}$ \\
\hline Tax2 & $\begin{array}{ll}-.0968455 & 0.863 \\
\end{array}$ & $\begin{array}{ll}-.2249481 \quad 0.694 \\
\end{array}$ & $.0333386 \quad 0.054$ & $-.0968455 \quad 0.863$ \\
\hline Tax3 & $.302084 \quad 0.045$ & $1.43534 \quad 0.029$ & $.038269 \quad 0.060$ & $.302084 \quad 0.045$ \\
\hline Age & $.0047289 \quad 0.708$ & $.0039917 \quad 0.743$ & $.0002143 \quad 0.586$ & $.0047289 \quad 0.708$ \\
\hline Log (employment) & $-.8552694 \quad 0.591$ & $-7.831466 \quad 0.174$ & $.0359367 \quad 0.467$ & $-.8552694 \quad 0.591$ \\
\hline Log (employment)2 & $.2438749 \quad 0.108$ & $.9556885 \quad 0.097$ & $.0020351 \quad 0.677$ & $.2438749 \quad 0.108$ \\
\hline Concentration1 & $\begin{array}{ll}-.0777854 & 0.909 \\
\end{array}$ & $\begin{array}{ll}-.3236137 & 0.621 \\
\end{array}$ & $\begin{array}{ll}0004312 & 0.984 \\
\end{array}$ & $\begin{array}{ll}-.0777854 & 0.909 \\
\end{array}$ \\
\hline Concentration2 & $.9140179 \quad 0.158$ & $.6626426 \quad 0.273$ & $.0100868 \quad 0.619$ & $.9140179 \quad 0.158$ \\
\hline Multi-facility & $1.042265 \quad 0.050$ & $\begin{array}{ll}8177985 & 0.139 \\
\end{array}$ & $-.0093245 \quad 0.562$ & $1.042265 \quad 0.050$ \\
\hline Firm intl & $1.29889 \quad 0.091$ & $1.150229 \quad 0.134$ & $.0105952 \quad 0.672$ & $1.29889 \quad 0.091$ \\
\hline Firm quoted & $\begin{array}{ll}-.3747591 \quad 0.578 \\
\end{array}$ & $\begin{array}{lll}-.1538385 & 0.822 \\
\end{array}$ & $\begin{array}{ll}.0081486 & 0.726 \\
\end{array}$ & $\begin{array}{ll}-.3747591 & 0.578 \\
\end{array}$ \\
\hline Primary cust & $-1.011436 \quad 0.067$ & $-.7422391 \quad 0.220$ & $-.0232598 \quad 0.169$ & $-1.011436 \quad 0.067$ \\
\hline Marketscope1 & $.0105878 \quad 0.992$ & $.9556885 \quad 0.097$ & $-.0641135 \quad 0.043$ & $.0105878 \quad 0.992$ \\
\hline Marketscope2 & $\begin{array}{ll}-.8687797 & 0.216 \\
\end{array}$ & $-1.22517 \quad 0.065$ & $-.0268562 \quad 0.214$ & $\begin{array}{ll}-.8687797 & 0.216 \\
\end{array}$ \\
\hline Marketscope3 & $1.043586 \quad 0.212$ & $1.122838 \quad 0.179$ & $\begin{array}{l}0127429 \quad 0.628 \\
\end{array}$ & $1.043586 \quad 0.212$ \\
\hline Instrument Env. Perf. & $.3820423 \quad 0.000$ & $2356673 \quad 0.001$ & $.0063639 \quad 0.013$ & $.3820423 \quad 0.000$ \\
\hline Fit Env. R\&D & $.3003784 \quad 0.850$ & $-5.78 \mathrm{e}-10 \quad 0.209$ & $.0139169 \quad 0.788$ & $.3003784 \quad 0.850$ \\
\hline R-squared & 0.2159 & 0.2099 & 0.0990 & 0.2159 \\
\hline Observations & 1656 & 1656 & 3681 & 1656 \\
\hline
\end{tabular}


PANEL C

\begin{tabular}{|c|c|c|c|c|}
\hline Dependent variable: & Main Regression (1) & Total R\&D (2) & Env. Perf. Binary (3) & Shipments (4) \\
\hline Business Perf. & Coeff. P. Value & P.Value & P. Value & P. Value \\
\hline Stringency1 & $\begin{array}{ll}0869374 & 0.219 \\
\end{array}$ & $.0561415 \quad 0.459$ & $.0868955 \quad 0.223$ & $4.99 \mathrm{e}+09 \quad 0.389$ \\
\hline Stringency 3 & $-.1406783 \quad 0.051$ & $\begin{array}{ll}-.0778881 & 0.257\end{array}$ & $-.1412988 \quad 0.036$ & $-8.86 e+09 \quad 0.156$ \\
\hline Tech-standards1 & $.0632713 \quad 0.392$ & $.0505136 \quad 0.528$ & $\begin{array}{ll}.0641942 & 0.451 \\
\end{array}$ & $-1.93 e+10 \quad 0.006$ \\
\hline Tech-standards2 & $.0293627 \quad 0.687$ & -.02038930 .808 & $.0308771 \quad 0.750$ & $-1.42 \mathrm{e}+10 \quad 0.008$ \\
\hline Tech-standards3 & $\begin{array}{ll}.0299407 & 0.700 \\
\end{array}$ & $\begin{array}{ll}.0095498 & 0.919 \\
\end{array}$ & $.0302814 \quad 0.708$ & (dropped) \\
\hline Perf-standards 1 & $-.1146602 \quad 0.167$ & $-.0907908 \quad 0.263$ & $-.1108494 \quad 0.367$ & $7.81 \mathrm{e}+09 \quad 0.391$ \\
\hline Perf-standards2 & $\begin{array}{ll}.0843931 & 0.296 \\
\end{array}$ & $-.0549574 \quad 0.519$ & $-.0802483 \quad 0.607$ & $3.87 \mathrm{e}+09 \quad 0.498$ \\
\hline Perf-standards3 & -.11120050 .279 & $\begin{array}{ll}-083422 & 0.459 \\
\end{array}$ & $\begin{array}{lll}.1068991 & 0.564 \\
\end{array}$ & (dropped) \\
\hline Tax1 & $.0780998 \quad 0.130$ & $\begin{array}{ll}0735657 & 0.156 \\
\end{array}$ & $0778749 \quad 0.13$ & $5.30 \mathrm{e}+07 \quad 0.992$ \\
\hline Tax2 & $\begin{array}{ll}0303942 & 0.481 \\
\end{array}$ & $.0368194 \quad 0.403$ & $.0318808 \quad 0.556$ & $\begin{array}{ll}1.37 \mathrm{e}+09 & 0.777 \\
\end{array}$ \\
\hline Tax3 & $\begin{array}{ll}.0878812 & 0.113\end{array}$ & $-.1025273 \quad 0.093$ & $\begin{array}{ll}.0871761 & 0.173\end{array}$ & $4.19 \mathrm{e}+09 \quad 0.442$ \\
\hline Age & $-.0043678 \quad 0.000$ & $-.0036149 \quad 0.000$ & $-.0043621 \quad 0.000$ & $-6.23 e+07 \quad 0.478$ \\
\hline Log (employment) & $-.0176274 \quad 0.888$ & $.4926506 \quad 0.314$ & $\begin{array}{ll}-.0154929 & 0.904 \\
\end{array}$ & $-2.20 \mathrm{e}+11 \quad 0.000$ \\
\hline $\log (\text { employment })^{2}$ & $.0053395 \quad 0.682$ & $\begin{array}{ll}.0435979 & 0.390\end{array}$ & $.0052533 \quad 0.676$ & $2.15 \mathrm{e}+10 \quad 0.000$ \\
\hline Concentration1 & $.1797393 \quad 0.001$ & $.2415721 \quad 0.000$ & $.1798128 \quad 0.001$ & $-9.78 \mathrm{e}+09 \quad 0.049$ \\
\hline Concentration 2 & $\begin{array}{ll}.0564358 & 0.291 \\
\end{array}$ & $.1169826 \quad 0.017$ & $\begin{array}{ll}.0562173 & 0.280\end{array}$ & $-7.46 \mathrm{e}+09 \quad 0.087$ \\
\hline Multi-facility & $.0309915 \quad 0.474$ & $.0524174 \quad 0.239$ & $.0298564 \quad 0.467$ & $-6.83 e+09 \quad 0.125$ \\
\hline Firm intl & $.0794885 \quad 0.235$ & $\begin{array}{ll}.0672878 & 0.323 \\
\end{array}$ & $\begin{array}{ll}.0871761 & 0.17 \\
\end{array}$ & $-4.72 \mathrm{e}+08 \quad 0.939$ \\
\hline Firm quoted & $.0807965 \quad 0.172$ & $0937432 \quad 0.179$ & $.0814086 \quad 0.168$ & $2.87 \mathrm{e}+09 \quad 0.605$ \\
\hline Primary cust & $.0579448 \quad 0.207$ & $.0454107 \quad 0.353$ & $.0576722 \quad 0.237$ & $1.26 \mathrm{e}+10 \quad 0.006$ \\
\hline Marketscope1 & $.0579448 \quad 0.207$ & $\begin{array}{ll}-.0832841 & 0.309\end{array}$ & $\begin{array}{ll}-.090643 & 0.370 \\
\end{array}$ & $-1.17 \mathrm{e}+10 \quad 0.188$ \\
\hline Marketscope 2 & $\begin{array}{ll}.0730595 & 0.194 \\
\end{array}$ & $.0606414 \quad 0.296$ & $.0725328 \quad 0.231$ & $-3.05 e+09 \quad 0.524$ \\
\hline Marketscope3 & $\begin{array}{ll}.0535669 & 0.433 \\
\end{array}$ & $\begin{array}{ll}-.0671934 & 0.342\end{array}$ & $-.0537643 \quad 0.425$ & $-7.94 \mathrm{e}+08 \quad 0.907$ \\
\hline Fit Env. Perf. & -.00070850 .966 & .006842 .0 .758 & -.04253290 .966 & $1.06 \mathrm{e}+09 \quad 0.500$ \\
\hline Fit $R \& D$ & $.2259759 \quad 0.089$ & $4.68 \mathrm{e}-11 \quad 0.230$ & .2256452 .0 .088 & $1.08 \mathrm{e}+09 \quad 0.855$ \\
\hline (pseudo) R-squared & 0.0506 & 0.0504 & 0.0506 & 0.0508 \\
\hline Observations & 1656 & 3574 & 3574 & 1767 \\
\hline
\end{tabular}




\section{Environmental R\&D Equation}

In our first equation, the dependent variable is a binary variable indicating the existence or not of a specific R\&D budget for environmental matters in the facility. It is estimated using a Probit, with an instrument defined as the average percentage of facilities in the same sector and same country with a specific environmental R\&D budget. This variable, INSTRUMENT R\&D, has a positive and strongly significant coefficient.

Regarding the environmental policy variables, we first find that perceived policy stringency plays a significant role. If the environmental policy regime is perceived as "very stringent" (STRINGENCY3), this has a positive and significant impact on the probability of having a specific $R \& D$ budget devoted to environmental issues. Analogously, when the regime is perceived as being "not particularly stringent" (STRINGENCY1), it has a negative impact on the probability to have a specific environmental R\&D budget. Policy instrument choice also matters. When performancebased standards are perceived as "moderately important" or "very important" (PERFSTANDARDS2 and PERF-STANDARDS3), this has a positive and significant impact on the probability of having a specific R\&D budget for pollution control. None of the other policy variables has a significant coefficient.

These results provide support for the "weak" version of $\mathrm{PH}$, but not for the "narrow" one, since flexible instruments like pollution taxes are not those with the strongest impact on environmental innovation. This may be simply due to the fact that these instruments are not very widespread (Johnstone et al., 2007, and OECD, 2006), and that, when they are used, they are not very stringent (OECD, 2006). However, the finding that performance standards have an impact, but not technology-based standards, is reassuring. Indeed, when technology-based standards are used, the pollution control technology to be adopted by facilities is prescribed so that, not surprisingly, they are not induced to identify other options through investment in R\&D. With performance standards, facilities have more flexibility to choose how they will meet standards and thus the returns on research are potentially greater. Actually, our results suggest that more 
"flexible" regulations (performance standards) have more impact on environmental innovation than more prescriptive measures (technology-based standards), which is in line with Porter's narrow version.

Among the control variables, it is noteworthy that Japanese facilities are significantly more likely to have a specific R\&D budget for environmental matters than the reference country (Canada). The facilities whose market scope is regional (MARKETSCOPE3) have a lower probability to have a specific R\&D budget for environmental matters than the reference case (local markets). This suggests that facilities which put the emphasis on their local market may have a greater incentive to signal their willingness to improve their environmental performance. Furthermore, facilities in more concentrated markets (CONCENTRATION1, CONCENTRATION2) have a higher probability to invest in research on environmental issues. This contrasts with the result in Brunnermeir and Cohen (2003) who find that environmental R\&D is more important in more competitive industries. However, we find no effect of facility size on the probability to have a specific environmental R\&D budget.

Our results are comparable with those of Jaffe and Palmer (1997) who find a significant impact of environmental regulation on R\&D expenditures, but no effect on patents. Arimura et al. (2007b) have also used this database to assess whether more stringent environmental policy regimes are associated with greater environmental innovation. They find, as in this paper, that the perceived stringency of the environmental policy regime plays a positive and significant role, but that none of the other policy variables is significant. However, their econometric approach is different than ours ${ }^{17}$.

\section{Environmental Performance Equation}

In this case, the number of observations is reduced to 1656, primarily because there are a large number of missing observations for the environmental performance question

\footnotetext{
${ }^{17}$ As we have seen, they use a bivariate probit model in which the other dependent variable is « environmental accounting », reflecting whether or not a facility has put in place an environmental accounting system.
} 
relating to "global pollutants". Given the continuous nature of the ENVIRONMENTAL PERF variable (described above), an OLS model is applied. In this equation, an instrument is used, INTRUMENT ENV PERF, which is the average environmental performance of the facilities in the same sector in the same country. It has a positive coefficient, as expected, and it is highly significant. Furthermore, the variable FIT ENVIRONMENTAL R\&D is the fitted value of the preceding equation that was estimated with a similar instrument as that just mentioned. The coefficient of this fitted variable has a positive sign, as expected, but is not significant.

Regarding the environmental policy variables, most are positive and significant, suggesting, as expected, that more stringent policies improve environmental performance. Generally speaking, this is consistent with previous literature on the effectiveness of environmental policy in reducing pollution (Magat and Viscusi, 1990; Gray and Deily, 1996; Laplante and Rilstone, 1996; Lanoie et al., 1998; Lanoie et al., 2002).

Three results are particularly noteworthy. First, the perceived stringency of the performance standards has a more important impact than that of the technology-based standards as suggested by theory ${ }^{18}$. As far as we know, this is a new result in the literature since previous researchers did not have access to information detailed enough to investigate this question.

Second, when the environmental policy regime is perceived as "very stringent" (STRINGENCY3), this has a positive and significant impact on environmental performance. Analogously, when the regime is perceived as "not particularly stringent" (STRINGENCY1), it has a negative and significant impact on environmental performance.

Third, environmental taxes have a significant impact only when they are perceived as being very important (TAX3). This suggests that taxes provide incentives to reduce

\footnotetext{
${ }^{18}$ A Wald test $(F 3,1614)=2.12$ shows that we can reject the hypothesis that the coefficients of the performance standards are equal to those of the technology standards at the $10 \%$ confidence level.
} 
pollution only when they are high enough, which is not very common in OECD countries (OECD, 2006). Again, there are few comparable results in the literature given constraints on data availability.

Among the control variables, the dummy variable for Hungarian facilities is negative and significant, indicating they are less likely to report improvements in environmental performance than the reference country (Canada). For France and the U.S., the variable is positive and significant. The sector dummy variables are all negative relative to the reference sector (Recycling and other). The SIZE, the AGE, the market SCOPE and the market CONCENTRATION variables do not have a significant impact.

Interestingly, the fact that primary customers are primarily households and/or retailers (PRIMARY CUST.), as opposed to other manufacturing firms, or other manufacturing units within the same firm, has a negative impact on reported environmental performance. This may suggest that the environmental performance is becoming more important in business-to-business (B2B) trading. For instance, facilities with ISO14001 are required to check the environmental performance of their suppliers. Finally, the finding that a facility belongs to a MULTI-FACILITY firm is associated with improved environmental performance suggests that there could be beneficial transfers of technology or expertise across facilities.

Estimates of environmental performance are included in two other papers of the OECD project (Johnstone et al., 2007b, Darnall et al., 2007). It is very difficult to compare our results with those of Johnstone et al. (2007b) since they estimate distinct equations for three types of pollutants (water, air, waste). Darnall et al. (2007) also find that regulatory influences have a positive impact on the overall environmental performance of facilities. However, they use an aggregate measure of the stringency of environmental policy regimes (issued from a factor analysis), and not individual measures as we do. Furthermore, they find that facilities with an environmental R\&D budget have better environmental performance but, contrary to us, they do not instrument this variable. 


\section{Business Performance Equation}

Given the nature of the dependent variable the BUSINESS PERFORMANCE equation is estimated with an Ordered Probit model (1656 observations). The variable FIT ENVIRONMENTAL PERF is the fitted value of the preceding equation that was estimated with a proper instrument ${ }^{19}$. The variable FIT ENVIRONMENTAL R\&D is also the fitted value of the ENVIRONMENTAL R\&D equation. This variable is positive and significant (at the $10 \%$ level). With respect to our hypothesised chain of causality, this implies that the stringency of the environmental policy regime (STRINGENCY3) influences ENVIRONMENTAL R\&D positively, which, in turn, has a positive effect on business performance. When we multiply the two relevant coefficients, we obtain the indirect positive impact of STRINGENCY 3 on business performance $(\approx+0,05)$. To our knowledge, this is the first time that these channels of influence suggested by Porter are detected empirically.

However, the direct effect of STRINGENCY 3 on business performance is negative, and the size of this effect is larger in absolute value than the positive indirect effect described above $(-0,14)$. In terms of the $\mathrm{PH}$, one can say that "innovation only partially offset the costs of complying with environmental policies". This may mean, for instance, that a large part of the investments necessary to comply with regulation represent additional production costs, such as through investment in end-of-pipe abatement. While some of these costs may be offset by the efficiency gains identified through investment in R\&D, the net effect remains negative. This intuition is indirectly confirmed by Frondel et al. (2007) who find that the decision to invest in end-of-pipe technologies is linked to the stringency of environmental policies, while the decision to invest in integrated clean production is rather influenced by "cost savings" motivations ${ }^{20}$. No other environmental policy variable is significant, nor is the FIT ENVIRONMENTAL PERF variable.

\footnotetext{
${ }^{19} \mathrm{PH}$ does not necessarily imply that the environmental performance influences business performance, and the nature of the results was not altered without the variable FIT ENVIRONMENTAL PERF.

${ }^{20}$ One of the questions in the questionnaire was: «How important do you consider the following motivations to have been with respect to the environmental practices of your facility ?" Cost savings was one of the potential items to be evaluated by the respondents.
} 
Among the control variables, we find that American, Norwegian, German, Japanese and French facilities in the sample have a lower reported business performance than those of the reference country, Canada. The facility's AGE has a negative influence on business performance, which may suggest that older facilities have older and less productive technologies. Finally, as expected, strong market concentration (CONCENTRATION1) has a positive effect on business performance.

Darnall et al. (2007) also estimate a BUSINESS PERFORMANCE equation with this database using, as we saw earlier, a bivariate probit in which ENVIRONMENTAL PERFORMANCE is the second dependent variable. They find that the ENVIRONMENTAL PERFORMANCE has a positive impact on BUSINESS PERFORMANCE, although the STRINGENCY of environmental policy is found, as in our analysis, to have a negative impact on BUSINESS PERFORMANCE. The link between ENVIRONMENTAL R\&D and BUSINESS PERFORMANCE is not investigated.

Other researchers have examined the link between environmental performance and business performance with a simpler approach than that developed here, paying less attention to the role of environmental policy and environmental $R \& D$, and making no attempt to deal with endogeneity issues (Hart and Ahuja, 1996; Russo and Fouts, 1997; Konar and Cohen, 2001). In general, they find a positive relationship between environmental performance and business performance.

Regarding our robustness checks, when we use investment in general R\&D as a measure of innovation induced by environmental policies (column 2), we have less support for the "weak version" of the PH. Indeed, in the R\&D equation (Panel A), only the variable TECH-STANDARDS3 is weakly significant. The results in the Environmental Performance equation (Panel B) are largely unaffected by the change. In the Business Performance equation, the coefficient of FIT TOTAL R\&D is positive as expected, but no longer significant. Interestingly, the variable STRINGENCY3 is no longer negative and significant, but the variable TAX3 becomes negative and weakly significant 
indicating that, overall, environmental policies are costly in terms of business performance, which was also the conclusion in our preferred version.

When we use a " $0-1$ " environmental performance variable (column 3 ), there is no change in the Environmental R\&D equation, and almost no change in the Environmental Performance and Business Performance equations. Finally, when we use the evolution of shipments as a measure of business performance (column 4), the two first equations are, of course, not modified. In the Business Performance equation, the coefficient of FIT ENVIRONMENTAL R\&D retains the expected positive sign, but is no longer significant. Interestingly, as in column (2), the variable STRINGENCY3 is no longer negative and significant, but the variable TECH STANDARD2 becomes negative and significant again confirming the finding that environmental policy has a detrimental effect on financial performance. Overall, the results of our preferred version appear robust.

\section{Concluding remarks}

Overall, the richness of this database has allowed us to assess the empirical validity of the Porter Hypothesis, through improved understanding of the channels of influence between environmental policy and business performance. In general, we find strong support for the 'weak' version of the hypothesis, qualified support for the 'narrow' version of the hypothesis, and qualified support for the 'strong' version of the hypothesis. The last two sets of results have important public policy implications.

With respect to the 'weak' version of the hypothesis, it is reassuring to find that environmental policy induces innovation (as reflected in R\&D expenditures). Indeed, it would be surprising if this were not the case. Since environmental policy changes the relative price of environmental factors of production, it would be surprising if increased policy stringency did not encourage facilities to identify means of economising on their use. 
With respect to the 'narrow' version of the hypothesis, the finding that more flexible 'performance standards' are more likely to induce innovation than more prescriptive 'technology-based standards' has important implications for public policy, and supports the trend toward 'smart regulation' found in many OECD countries. Performance standards induce innovation by giving firms the incentive to seek out the optimal means to reduce their environmental impacts. While we do not find this to be true of marketbased instruments, this may be due to the fact that, in practice, such measures are frequently applied at too low a level to induce innovation.

And finally, there is some indirect support for the 'strong' version of the hypothesis through the finding that environmental policy induces investment in environmental R\&D, and this, in turn, has a positive effect on business performance. However, the direct effect of environmental policy stringency on business performance is negative, and greater in size than the indirect positive effect mediated through R\&D. As noted above, this may mean, for instance, that a large part of the investments necessary to comply with regulation represent additional production costs, such as through investment in end-ofpipe abatement. In terms of the $\mathrm{PH}$, "innovation only partially offset the costs of complying with environmental policies". 


\section{References}

Alpay, E., S. Buccola and J. Kerkvliet (2002) 'Productivity Growth and Environmental Regulation in Mexican and U.S. Food Manufacturing', American Journal of Agricultural Economics 84(4):887-901.

Ambec S. and P. Barla (2002), "A theoretical foundation of the Porter Hypothesis", Economics Letters 75, 355-360.

Ambec, S. and P. Barla (2005) "Quand la réglementation environnementale profite aux pollueurs : survol des fondements théoriques de l'hypothèse de Porter" working paper GREEN, Laval University, forthcoming in L'Actualité économique.

Ambec, S. and Barla, P. (2006) 'Can Environmental Regulations be Good for Business? An Assessment of the Porter Hypothesis’ Energy Studies Review 14, 42-62.

Ambec, S. and P. Lanoie (2007) 'When and why does it pay to be green?' working paper GAEL Grenoble, http://www.grenoble.inra.fr/Docs/pub/A2007/gael2007-05.pdf

Arimura, T., A. Hibiki and H. Katayama (2007b) 'Is a Voluntary Approach and Effective Environmental Policy Instrument' Resources for the Future Discussion Paper RFF 07-31.

Arimura, T., Hibiki, and A., Johnstone, N. (2007a) "An Empirical Study of Environmental R\&D: What Encourages Facilities to be EnvironmentallyInnovative?" in Johnstone, N. (Ed.) Corporate Behaviour and Environmental Policy Cheltenham UK: Edward Elgar in association with OECD.

Arimura, T.H., A. Hibiki, S. Imai and M. Sugino (2005), "Empirical Analysis of the Impact that Environmental Policy has on Technological Innovation", Paper prepared for Final Meeting of Collaboration Projects 2004 "Sustainable Economic Growth and the Challenges of Global Warming" at The Economic and Social Research Institute, Cabinet Office, Government of Japan http://www.esri.go.jp/en/prj-2004_2005/kankyou/kankyou16/syousai-e.html

Berman, E. and L.T.M. Bui (2001) 'Environmental regulation and productivity: evidence from oil refineries' The Review of Economics and Statistics 83(3): 498-510.

Brunnermeier, S.B. and M.A. Cohen (2003), 'Determinants of environmental innovation in US manufacturing industries', Journal of Environmental Economics and Management 45: 278-293.

Burtraw, D. (2000) "Innovation Under the Tradable Sulfur Dioxide Emission Permits Program in the U.S. Electricity Sector", Discussion Paper 00-38, Resources For the Future (RFF), Washington. 
Darnall, N. (2007) "Environmental Regulations, Efficiency Offsets and Organizations'Performance" mimeo presented at the Grenoble Conference on Environment, Innovation and Performance, June $5^{\text {th }}$.

Darnall, N. G.; Jolley, J. and Ytterhus, B. (2007) "Understanding the Relationship between a Facility's Environmental and Financial Performance" in Johnstone, N. (Ed.) Corporate Behaviour and Environmental Policy Cheltenham UK: Edward Elgar in association with OECD.

Dillman, D. (2000) Mail and Internet Surveys: The Tailored Design Method, John Wiley.

Frondel, M.; Horbach, J. and Rennings, K. (2007) "End-of-Pipe or Cleaner Production? An empirical Comparison of Environmental Innovation Decisions Across OECD Countries" in Johnstone, N. (Ed.) Corporate Behaviour and Environmental Policy Cheltenham UK: Edward Elgar in association with OECD.

Gabel, H.L. and B. Sinclair-Desgagné (2002), 'The Firm, its Procedures, and Win-Win Environmental Regulations' in Henk Folmer et al. Frontiers of Environmental Economics (Cheltenham, UK).

Gallagher, K.P. and F. Ackerman (2000) Trade Liberalization and Pollution Intensive Industry in Developing Countries: A Partial Equilibrium Approach. The Environmental Assessment of Trade Liberalization Agreements. Paris: OECD

Gray, W.B. and R.J. Shadbegian (1998) 'Environmental regulation investment timing, and technology choice', The Journal of Industrial Economics XLVI(2): 235-256.

Gray, W.B. and R.J. Shadbegian (2003) 'Plant vintage, technology, and environmental regulation', Journal of Environmental Economics and Management 46, 384-402.

Gray,W. and M.E. Deily (1996) "Compliance or Enforcement: Air Pollution Regulation in the U.S. Steel Industry" Journal of Environmental Economics and Management 31, 96-111.

Greaker, M. (2003), 'Strategic Environmental Policy; Eco-dumping or a Green Strategy?', Journal of Environmental Economics and Management 45, 692-707.

Hart, S.L. and G. Ahuja (1996) « Does it Pay to be Green? An Empirical Examination of the Relationship between Emission reduction and Firm Performance" Business Strategy and the Environment 5, 30-37.

Hausman, J., (1996) "Valuation of New Goods under Perfect and Imperfect Competition," in T. Bresnahan and R. Gordon, eds., The Economics of New Goods, Studies in Income and Wealth, Vol. 58, Chicago: National Bureau of Economic Research.

Hausman, J., G. Leonard, and J.D. Zona (1994) "Competitive Analysis with Differentiated Products," Annales d'Economie et de Statistique, 34, 159-180. 
Henriques, I., Sadorsky, P. and S. Kerekes (2007) "Environmental Management Systems and Practices: An International Perspective" in Johnstone, N. (Ed.) Corporate Behaviour and Environmental Policy Cheltenham UK: Edward Elgar in association with OECD.

Jaffe, A. B.; Peterson, S. R.; Portney, P. R. and R.N. Stavins (1995) «Environmental Regulation and International Competitiveness: What Does the Evidence Tell Us? » Journal of Economic Literature 93, 12,658-12,663.

Jaffe, A.B. and K. Palmer (1997) "Environmental Regulation and Innovation: A Panel Data Study" Review of Economics and Statistics 79(4): 610-619.

Japan Ministry of Internal Affairs and Communication, Statistics Bureau (2003) Survey of Research and Development http://www.stat.go.jp/english/data/kagaku/index.htm

Jaumotte, F. and N. Pain (2005) 'From Ideas to Development: The Determinants of R\&D and Patenting' OECD Economics Department Working Paper No. 457 $\mathrm{ECO} / \mathrm{WKP}(2005) 44$.

Johnstone, N. (2005) 'Tradeable Permits: Implications for Monitoring and Enforcement' in D. Helm (ed.) Climate Change Policy (Oxford: Oxford University Press)

Johnstone, N. and J. Labonne (2006) 'Environmental Policy, Management and Research and Development' in OECD Economic Studies, Vol. 46.

Johnstone, N., Serravalle, C.; Scapecchi, P. and J. Labonne (2007a) "Public Environmental Policy and Corporate Behaviour: Project Background, Overview of the Data and Summary Results" in Johnstone, N. (Ed.) Corporate Behaviour and Environmental Policy Cheltenham UK: Edward Elgar in association with OECD.

Johnstone, N.; Glachant, M.; Serravalle, C.; Riedinger, N. and P. Scapecchi (2007b) "Many a Slip Twixt the Cup and Lip: Direct and Indirect Policy Incentives to Improve Corporate environmental Performance" in Johnstone, N. (Ed.) Corporate Behaviour and Environmental Policy Cheltenham UK: Edward Elgar in association with OECD.

Konar, S. and M.A. Cohen (2001) "Does the Market Value Environmental Performance?" Review of Economics and Statistics 83, 281-289.

Lanoie, P.; Laplante, B.and J. Foulon (2002) «Incentives for Pollution Control: Regulation or Information?» Journal of Environmental Economics and Management vol. 44, 169-187.

Lanoie, P.; Patry, M.; Lajeunesse, R. (2005) « Environmental Regulation and Productivity : New findings on the Porter Hypothesis », mimeo, HEC Montréal. 
Lanoie, P.; Thomas, M. and J. Fearnley (1998) «Firm Responses to Effluent Regulations: Pulp and Paper in Ontario, 1985-1989» Journal of Regulatory Economics 13 (1998) : 103-120.

Mani, M. and D. Wheeler (1997) "In Search of Pollution Havens? Dirty Industry Migration in the World Economy" World Bank Working Paper, Washington.

Mohr R.D. (2002), "Technical Change, External Economies, and the Porter Hypothesis", Journal of Environmental Economics and Management 43(1), 158-168.

Nelson R.A., T. Tietenberg and M.R. Donihue (1993) 'Differential Environmental Regulation: Effects on electric utility capital turnover and emissions' The Review of Economics and Statistics 75(2): 368-373.

Nevo A. (2000a) "Measuring Market Power in the Ready-to-Eat Cereal Industry," Econometrica, 69, 307-342

Nevo A. (2000b) "Mergers with Differentiated Products: The Case of the Ready-to-Eat Cereal Industry," Rand Journal Economics, 31, 395-421.

Oates, E.; Palmer, K. and Portney, P. R. (1995) « Tightening Environmental Standards : The Benefit-Cost or the No-Cost Paradigm ? », Journal of Economic Perspectives, Vol. 9, no 4, 119-112.

Popp, D. (2006) "International Innovation and Diffusion of Air Pollution Control Technologies: The Effects of NOX and SO2 Regulation in the US, Japan, and Germany", Journal of Environmental Economics and Management, 51(1), 46-71.

Porter, M. (1991) “American Green Strategy” Scientific American 264, 168.

Porter, M. and C. van der Linde (1995) "Towards a New Conception of EnvironmentCompetitiveness Relationship" Journal of Economic Perspective 9, 97-118.

Reinhardt, F.L. (2000) Down to Earth: Applying Business Principles to Environmental Management Boston: Harvard Business School Press

Russo, M.V. and P.A. Fouts (1997) "A Resource-Based Perspective on Corporate Environmental Performance and Profitability" Academy of Management Journal 40, 534-559.

Simpson David and Robert L. Bradford (1996), 'Taxing Variable Cost: Environmental Regulation as Industrial Policy', Journal of Environmental Economics and Management 30(3), 282-300.

Statistics Canada Environmental Protection Expenditures in the Business Sector, Statistics Canada http://www.statcan.ca/english/freepub/16F0006XIE/free.htm

Tirole, J. (1989) Industrial Organization, MIT Press. 


\section{Liste des cahiers de recherche publiés \\ par les professeurs 2006-2007}

\section{Institut d'économie appliquée}

IEA-06-01 DOSTIE, BENOIT ET LÉGER PIERRE THOMAS. « Self-selection in migration and returns to unobservable skills », 88 pages

IEA-06-02 JÉRÉMY LAURENT-LUCCHETTI AND ANDREW LEACH. «Induced innovation in a decentralized model of climate change », 34 pages.

IEA-06-03 BENOIT DOSTIE, RAJSHRI JAYARAMAN AND MATHIEU TRÉPANIER. «The Returns to Computer Use Revisited, Again », 27 pages.

IEA-06-04 MiCHEL NORMANDIN. « The Effects of Monetary-Policy Shocks on Real Wages: A MultiCountry Investigation », 38 pages.

IEA-06-05 MiChel NORMAndin. « Fiscal Policies, External Deficits, and Budget Deficits », 50 pages.

IEA-06-06 J. DAVID CUMMINS, GEORGES DIONNE, ROBERT GAGNÉ AND ADBELHAKIM NOUIRA. «Efficiency of Insurance Firms with Endogenous Risk Management and Financial Intermediation Activities », 41 pages.

IEA-06-07 LUC BAUWENS AND JEROEN V.K. ROMBOUTS. «Bayesian Inference for the Mixed Conditional Heteroskedasticity Model », 25 pages.

IEA-06-08 LUC BAUWENS ARIE PREMINGER AND JEROEN V.K. ROMBOUTS. «Regime Switching Garch Models », 25 pages.

IEA-06-09 JEROEN V.K. ROMBOUTS AND TAOUFIK BOUEZMARNI. « Nonparametric Density Estimation for Positive Time Series », 32 pages.

IEA-06-10 JUSTIN LEROUX. «Cooperative production under diminishing marginal returns: Interpreting fixed-path methods », 25 pages.

IEA-06-11 JUSTIN LEROUX. « Profit sharing in unique Nash equilibrium characterization in the twoagent case », 16 pages.

IEA-06-12 ROBERT GAgNÉ, SIMON VAN NORDEN ET BRUNO VERSAEVEL. «Testing Optimal Punishment Mechnanisms under Price Regulation: the Case of the Retail Market for Gasoline », 27 pages. 
IEA-06-13 JUSTIN LEROUX. « A discussion of the consistency axiom in cost-allocation problems », 11 pages.

IEA-06-14 MAURICE N. MARCHON. «Perspectives économiques canadiennes dans un contexte international », 29 pages.

IEA-06-15 BENOIT DOSTIE. « Wages, Productivity and Aging », 30 pages.

IEA-06-16 TAOUfIK BOUEZMARni; JEROEN V.K. ROMBOUTS. « Density and Hazard Rate Estimation for Censored and $\alpha$-mixing Data Using Gamma Kernels », 22 pages.

IEA-06-17 BENOIT DOSTIE et DAVID SAHN. «Labor Market Dynamics in Romania during a Period of Economic Liberalization», 37 pages

IEA-06-18 DAFNA KARIV, TERESA V. MENZIES, GABRIELLE A. BRENNER ET LOUIS-JACQUES FILION «Transnational Networking and Business Success: Ethnic entrepreneurs in Canada», 36 pages. 
IEA-07-01 MOEZ BENNOURI, ROBERT CLARK, and JACQUES ROBERT. «Consumer Search and Information Intermediaries», 32 pages.

IEA-07-02 JEAN-FRANÇOIS ANGERS, DENISE DESJARDINS, GEORGES DIONNE, BENOIT DOSTIE and FRANÇOIS GUERTIN. «Poisson Models with Employer-Employee Unobserved Heterogeneity : An Aplicatin to Absence Data», 25 pages.

IEA-07-03 GEORGES DIONNE, ROBERT GAGNÉ AND ABDELHAKIM NOUIRA. «Determinants of Insurers' Performance in Risk Pooling, Risk Management, and Financial Intermediation Activities», 36 pages.

IEA-07-04 STEFAN AMBEC et PAUL LANOIE. «When and why does it pay to be green?», 40 pages.

IEA-07-05 CHRISTOS KOULOVATIANOS, LEONARD J. MIRMAN et MARC SANTUGINI. «Optimal growth and uncertainty : learning», 36 pages. 